\title{
THE GOVERNMENT OF DEPENDENCIES.
}

\section{TheOdORE S. Woolsex, Professor of International Law, Yale University.}

In every state with colonies, its government of them must depend upon two factors: (I) the prevailing theory of the dependent relation; (2) the constitutional limitations, if any, under which it lives. There are two theories to define the relationship between a state and its dependencies. One considers them property from which an income is to be drawn; the other considers them a kind of trust, to be administered for the benefit of their inhabitants.

A good example of the first is the Dutch rule in Java. The Javanese number approximately twenty-five millions. They are governed by two-fifths of one per cent of their number of Europeans. The island is considered a sort of huge farm by the government of the Netherlands. The method of administration, called the "culture system," is one of forced labor. Introduced in 1830 , under the influence of a more enlightened public sentiment it is now disappearing. At times it has paid a surplus as high as ten million dollars into the Dutch treasury: but this has given place to a deficit. Under it, the Dutch government discouraged European immigration, education and missionary labor. There was no autonomy. Generally speaking there was no private property. And the result was that the natives deteriorated in artistic, industrial and scientific processes.

If we look for examples of the other, the trust theory, we shall find a very general opinion that the British system is best worth copying. During the second quarter of the present century, Great Britain finally gave her various dependencies self-government, unrestricted trade and reform 
administrations, wherever practicable. In those climates where the white man can work and multiply, in Canada, Australia and New Zealand for instance, self-governing colonies have been developed, with large liberty of action, duties to protect domestic manufactures against British competition having even been permitted. In the minor colonies of the temperate zone, and in the tropics, where dependencies have been retained in the hands of the crown, the principle of self-sacrifice has still prevailed, and the results have justified it. For we find, on the whole, prosperity, contentment and loyalty. A blind attachment to the opposite theory has cost Spain her colonies, and makes those of France, in the opinion of enlightened Frenchmen like M. Hanotaux and M. Leroy-Beaulieu, a failure. Now under the system of Great Britain, she spends and her colonies do not contribute; she protects and they enjoy. A judge of the High Court of Calcutta, Mr. Cunningham, wrote in I882, "we have definitely abandoned the idea that the political connection of England and India can be a source of direct gain to any public body or to the English nation."

Where, then, does the profit of a state in the matter of dependencies come in? It comes from the enlarged opportunity for the energies of its surplus youth, and in that stimulated trade which follows the flag. This is peculiarly true in the case of Great Britain. Her narrow limits at home offer but restricted opportunity for business and agricultural activities; while, on the other hand, her long supremacy in manufactures of certain kinds and her control of the carrying trade, enable her to take peculiar advantage of the traffic with her dependencies, by which example other nations like Germany have been tempted, to their hurt.

When we are forced by circumstances to study a form of government for our own dependencies, we turn naturally, therefore, to those British territories which most resemble 
them, and seek to learn the secret of their success or the warning in their failure.

My subject in terms is general, relating to the government of all dependencies. I shall take the liberty of making it more specific, the government of our own. These are of two classes, those which are placed under our sovereignty and those which are placed under our protection. In the latter class is Cuba. By treaty Spain has relinquished her sovereignty in Cuba. She does not cede it to us; she simply lets it go, reciting the fact that the island is " to be occupied " by the United States. The result of this must be that the sovereignty remains in abeyance with reversion to the Cubans themselves. Spain recognizes our assumption of responsibility for Cuba's actions, until we are satisfied of its "pacification." To secure this was our avowed object in waging war; everything else which has been won, was an accident. To correspond to this responsibility and to enable us to make it good, we must have a certain power. This in Cuba's foreign relations is exclusive; in her domestic concerns it must be so shared between the Cubans and currselves as to give them that degree of autonomy which will fit them for eventual independence (either in our Union or separately), while retaining control enough to be correlative with our liabilities. Our first step very properly consists in military occupation, using our soldiers as a constabulary. This means order and better sanitation and protection to local industries and the revival throughout the length and breadth of the island, of all the arts of peace. To accomplish the desired end, this must be accompanied by the gradual resumption of civil government in all the municipalities, and by the formation of an island legislature to control internal affairs, subject to the veto of the United States representative.

All franchises should be in the hands of the native local authorities; the execution of the laws should be entrusted to native elected officers; the courts to judge causes under 
the local law should be Cuban also. We protect Cuba from outside aggression, and by veto from her own inexperience and folly, and prevent acts of hostility to ourselves. But the revenues of the island, after paying for the maintenance of our soldiers so long as they are necessary and of our few necessary officials, must be spent for her own benefit. This is a protectorate. Whether the issue of the protectorate is independence, or, as many believe, annexation, the process of education, of pacification, is the same. It consists, in a word, in granting as much control over internal affairs as the inhabitants are able to bear. And we must so regulate their duties and revenue laws and commercial rights, as to give them a prosperous life, even at our own cost, that is, if we wish the experiment to turn out well. Thus we should open the door to foreign trade on as favorable terms as to our own. Instead of regarding the traffic between Cuba and the states as coasting trade, we should open it to foreign ships. And between Spaniards and Cubans, we should not discriminate.

All this we can properly and lawfully do, because we have not assumed the Cuban's sovereignty; so far as they are concerned we are not tied down by our constitution. Here we see the difference between protected and ceded territory. In the cases of Porto Rico and the Philippines, we are under constitutional limitations. Here there is no presumption of future independence. They are our spoils of war, to govern as Spain did, or to govern as Great Britain would, so far as our constitution allows. All depends upon the kind of results we desire. Some government we must provide, nor is it clear that this task will be easily shifted to other shoulders. While the ratification of the peace treaty was still an open question, it was urged that this step committed the United States to nothing; that in the Philippines at least, cession would give place in time to a protectorate or a sale or the establishment of a republic. I do not think we should shirk the question of a permanent government for them, 
under any such illusion. Anything other than permanent possession, however desirable, will be most difficult. My reasons for this view are, first, that future surrender is sure to be construed as a confession of failure, and would hurt the national pride. We need not have assumed the burden, but having done so, it must be patiently and loyally borne. Then, too, it will be much less easy to relinquish sovereignty than it was to refuse it. It implies the favorable conjunction of three bodies, two legislative, one executive, against in the latter case one-third of the Senate. And lastly, the whole spirit and tendency of the European policy which we are following, forbids such surrender. It strengthens the loose tie, rather than loosens the strong one. France in Madagascar, converting a protectorate into a colony, and England in Egypt, only awaiting the right moment to make her own that territory which she has repeatedly promised to evacuate, are examples of this.

To return from this digression.

Between Porto Rico and the Philippines, both now equally under the sovereignty of the United States, there is a gulf fixed, climatic, social, racial, as well as geographical. In Porto Rico we find a settled society largely of European stock; law-abiding, fairly prosperous, in a healthful climate where our race can live and work, and whither it is likely to migrate until the opportunities are filled. Here are materials for a state after territorial apprenticeship. Or as an unorganized territory, we may watch it working out its ideas of self-government. For, when Congress sees fit to legislate, the government of Porto Rico should be laid as largely as possible upon the shoulders of its own people. Military rule should not be necessary, and a carpet-bag system would produce results which we can pretty definitely forecast. Native officials, a native legislature, the existing laws and municipal regulations should be the starting point. Upon the present system should gradually be engrafted those changes which reason and experience, theirs and ours, 
may suggest, and which Spain has heretofore prevented. There will be difficulties, there may be failure, but both are a means of education. And education in the art of selfgovernment, is what we aim at giving, unless our policy and our professions are alike disregarded.

The case of the Philippines stands on a far different footing. Cuba and Porto Rico are near our shores; the Philippines are far away. The first have long been within our sphere of influence; possession of the second, suddenly makes us an Asiatic power, and thrusts us without warning into the political and commercial melting pot of the Orient. The first are in the main civilized; the second on the whole savage. In the first, white men can live and work; in the second they can only make others work. The capacity for self-government may exist in the one, but not so clearly in the other. We may govern the one by reason; for the other we shall need force. Porto Rico will pay its own way. The Philippines are certain to be a heavy burden. These are some of the reasons which made the cession of the Philippines a vulnerable point in the peace treaty. That treaty is now ratified, and we must make the best of it.

I say nothing about the administration of Hawaii, for that is being laid down by Congress. I assume moreover that the Aguinaldo insurrection will be soon put down and the island of Luzon pacified. It is the next step, the government after order is restored, which is the crux of the whole problem.

And here our minds naturaily turn to India. The British rule in India is based upon conquest and maintained by force. By war the limits of dominion are constantly being extended. To justify the mastery of many millions of people by a handful of alien conquerors, has required generations of honest administration, giving continuous proof of altruistic effort. The governing class has wisely pursued a policy of indifferentism in the matter of religion, neither discriminating between beliefs already embraced, nor seeking 
to propagate its own. So far as practicable it has sought to administer elementary justice through native officials, whose ability is tested by competitive examination. The covenanted civil service is open to British youth by competition, with tenure of office during good behavior, promotion in reserve and a handsome retiring pension in the bacliground. It is a picked class, drawn from the flower of the race, with public school training behind it, and animated by a strong preference for the administrative, not the commercial career. It makes a study, a science, of the business of governing dependent races, and the result is a commendable esprit de corps. All of this is the consequence of historical development, nor has this ceased. Thus at present the benevolent despotism of the last generation seems to be giving place to a stricter adherence to legal forms. Complaint is made that promotion goes too much by seniority, taking too little account of proved capacity. The fall in the silver rupee, in which the covenanted receive pay, has made the service less desirable. Some of the commissionerships are too large and unwieldy for one man and should be divided. These are criticisms, but as things are, the competition is still keen and the class secured good.

At the head of the government stands the Secretary of State for India, guided by a Council and sitting in London. Next comes the Governor-General, commonly but not officially known as Viceroy, with an Executive Council made up of heads of departments, the Viceroy taking that of foreign affairs. This Council is enlarged into a legislative council by the addition of the Governor of that province in which it is held, of official delegates from Madras and Bombay, and of certain non-official representatives of European and of native communities. Then come the governors of the two presidencies, also with councils; the lieutenant-governors of Bengal, the Punjab and the Northwestern Provinces; the chief commissioners of other provinces, together forming a class subordinate to the Viceroy. 
Under these are the 238 districts, grouped into commissionerships, their heads being called collector magistrates or deputy-commissioners. These are both fiscal and judicial officers, but concern themselves also with everything under the sun, from police to agriculture, from road-making to the social life of the people. For they are "the representatives of a paternal, not a constitutional government."*

'The districts containing an average of over 800,000 people, are in turn subdivided, this being the final unit of administration. The laws enforced are British acts, Indian Council enactments, native laws and native customs. The judicial jurisdiction corresponds largely to the magisterial and fiscal, and one of the curious features is the frequent union of two out of the three characters in the same person. A soldier also is sometimes made a district officer.

Fach province has its own judicial system, with a chain of authorities ending in the High Court, and to this law, so interpreted, all alike are subject. The characteristics of the whole system appear to be, paternalism, comprehensiveness, justice and order. The great majority of the minor civil offices are filled by natives; the higher judges are mostly European. Indeed the suggestion to place non-official Europeans under the jurisdiction of any natives created a tempest of opposition.

The results of British administration in India have been splendid. It has kept the peace, preserved order, built roads, railroads and irrigation works, brought justice to the humblest, lessened famine and pestilence, introduced state education, sanitation and dispensaries, freed trade from many burdens, simplified taxation, and has begun to introduce local self-government. A single detail further is pertinent. The imperial revenue is drawn chiefly from salt and opium monopolies and from the land tax; its expenditure, excluding capital or construction account, is about equal to its income.

* Encyc. Brit., Art. India, p. 769, ninth ed. 
Now very much of this system, particularly its basic ideas, will repay our study in considering the Philippines. We must practice religious toleration toward Christian and Mohammedan alike, even to the limit of indifferentism, yet not protecting abuses. We must keep a firm hand on the so-called civilized natives, who constitute one-half of the population, and yet educate them to some measure of local administration which they can in time undertake themselves. We must better communications and build public works. We must raise revenue skillfully and spend it more and more on the country. We must get work out of an indolent race, without slavery or its equivalent in contract labor, probably by introducing it to new wants. Life is necessarily indolent, where existence is so ridiculously easy. We must guide the savage half with the strength which he will respect and the courage which he will admire. Justice and good faith are essential in dealing with both classes: justice, inexpensive, swift and incorruptible, administered by a permanent trained service with bigher ideals than personal advantage. All of this is suggested by the British rule in India; it is essential to success; how can it be made practicable? Here we come in sight of our constitutional limitations, for it is the merest folly to trace out an ideal course and langh away the obstacles.

Let us assume that the United States may acquire territory, when and how it chooses. Let us grant that there is no obligation, either now or in the remote future, to form this territory into states. Nevertheless the moment Congress begins to legislate for the Philippines and establishes there civil government, whether on the lines above indicated or on any others, that moment the constitutional guarantees begin to work. This was the case in the unorganized territory of Alaska. In accordance with these guarantees, though a legislative assembly and a delegate to Congress are prohibited, the rights of habeas corpus and of a jury trial are recognized, by statute.*

*23 U. S. Stats. pp. 24-27. 
These personal guarantees are contained in the body of the constitution and its amendments. They relate in general to the security of life, liberty and property. They include specifically religious freedom; free speech and a free press; the right of assembling and of petition; the right to bear arms; security from unreasonable search and seizure; freedom from the quartering of troops; the necessity of presentment by a grand jury on a capital charge; the right of compulsory process to secure witnesses; the aid of counsel when accused; above all the right of trial by jury.

It is to be noted that some of these provisions are by nature or in terms applicable to all the territory of the United States, while others, being civil rather than political rights, may be capable of limitation to the citizens of the states and their grantees under title of the people of the United States. This distinction is by no means certain: it is merely a possible loophole of escape, if the supreme court should be urged to deny the Philippines certain inconvenient rights, that to bear arms, for instance.

But in order to stand on the safest possible ground let me place together here the guarantees concerning whose extension to all United States territory there can be little question.

First comes the right of trial by jury.

This is contained in the final clause of Section 2, Article III, as follows: "The trial of all crimes, except in cases of impeachment, shall be by jury; and such trial shall be held in the state where the said crimes shall have been committed; but when not committed within any state the trial shall be at such place or places as the Congress may by law have directed." This language is pretty clear, but by judicial construction it has been made still clearer.* In an illuminating and most judicial article upon the constitutional questions incident to the acquisition and government of

* Caltan v. Wilson, I27 U. S., 540, 550; Thompson v. Utah, I7o U. S., 343, 346. See also Am. Publ. Co. $v$. Fisher, 166 U. S., $464,466$. 
island territory by the United States (Harv. Law Rev., XII, No. 6), Judge Baldwin examines the origin of this jury trial provision, its phrasing, and its construction by the supreme court. He expresses the belief that unless the views of that court should be overruled, " they must lead to the conclusion that no conviction for crime could be had in any of our new possessions, after the establishment there of an orderly civil government, except upon a jury trial."

On the same plane with the right of trial by jury stand those guarantees, contained in the amendments to the constitution, which are neither inserted specifically for the benefit of the "people" of the United States, nor relate to rights merely political. Those most germane to our topic are here enumerated:

Slavery is forbidden in the United States "or any place subject to their jurisdiction."

Religious liberty is provided.

Indictment by a grand jury is necessary to a trial for an infamous crime.

No man can be compelled to give testimony against himself.

No person can be deprived of life, liberty or property without due process of law.

No cruel or unusual punishment may be inflicted.

If now these constitutional rights relating to persons and property extend to all the territories of the United States, they must exist in the Philippines, and must be taken account of in the question of governing the Philippines. The inhabitants of these islands are thought to number from eight to ten millions, of eighty distinct tribes which are classified by Professor Worcester as Negritos (the descendants of the aborigines), Mohammedan Malays, Pagan Malays, and civilized Malays, the latter being one-half of the whole. These domesticated Malays are described as fairly intelligent, but dishonest, untruthful, and so indolent that crops spoil for lack of laborers. 
Foreman, who had much fuller information than Worcester, and is the authority upon whom Worcester largely relies, gives a curious list of their virtues and vices, and confesses that he cannot understand their character. It is a succession of surprises, he says. They are hospitable, cleanly, sober and patient; they are incapable of gratitude, profligate, undependable, improvident, cruel, impertinent, superstitious, treacherous. The few in the cities imitate European usages; the many regard the European as a demoniacal being, or at least an enemy. All are liars, even in the confessional. "The native is so contumacious to all bidding," writes Foreman, "so averse to social order, that he can only be ruled by coercion, by the demonstration of force."

There is reason for this judgment. Of sixty-six provinces, nineteen under Spanish rule had a civil governor, fortyseven a military one; yet the civil governor was the head of carbineers and police, of the departments of education, prisons, health, works, forests, mines, agriculture, mails, telegraph; in charge of everything but the public funds, so that he could not have fallen far behind his military colleague as a reservoir of force.

Such are the domesticated half. The savage half range between docility and ferocity, between innocency and piracy, many tribes having never yielded to the Spaniard.

Now it we place such people as these in possession of such constitutional rights as those mentioned, we have a reductio ad absurdum. How can we establish over them a civil government which would be anything but a mockery, if we must concede indictment by grand jury for some crimes and trial by jury for all? It would mean the breakdown of any criminal system to which it was applied and unchecked crime means administrative failure. And in addition, unless by construction the other guarantees could be put out of reach, like edged tools rescued from children's hands, we might have to concede the right to bear arms to persons 
intending assassination; a free press, although teaching open sedition; the right of assembling when it endangered our sovereignty.*

As Judge Baldwin well says, to give half-civilized peoples the benefit of immunities framed by a civilized people for itself " would be a serious obstacle to the maintenance there of an efficient government. Every people under a written constitution must experience difficulties of administration that are unknown to nations like Great Britain which are unfettered by legal restraints imposed by former generations. It is part of the price that it pays for liberty, that new conditions must be dealt with in fundamentals, under old laws."

Nevertheless we need not despair of our ability to frame a suitable government for the Philippines, even if, as I believe, a civil government, under our constitution, is and must be for the indefinite future, inadmissible. We have still the military solution in reserve, and to that we have recourse by process of exclusion.

Govern we must. Civil government would mean chaos, if the personal guarantees go with it. No government can succeed there which is not based upon force. We need to place a benevolent despot in every district in the Archipelago. Therefore the military government is the only one possible. And this is dependent upon the inaction of Congress. Its constitutional basis lies in thefact that the United States as sovereign is responsible for the maintenance of justice and order, for the defence of its territory, for the protection of its subjects' rights. This duty is in the hands of Congress as part of its general rights, and also under the " needful rules and regulations" clause, regarding territory. Peuding action by Congress, this duty devolves upon the President, the Executive

* In Mormon Ch. v. ס. S. (136 U. S. 44) Mr. Justice Bradley said for the Court, "Doubtless Congress in legislating for the territories would be subject to those fundamental limitations in favor of personal rights, which are formulated in the Constitution and its amendments; but these limitations would exist rather by inference and the general spirit of the Constitution from which Congress derives all its powers, than by any express and direct application of its provisions." 
head of the nation and Commander-in-Chief of both army and navy. The law applicable would not be martial law, for that implies war, or insurgency; it would not be military law except as to the discipline of the army itself; it would be simply the will of the President, but expressed so far as practicable in terms of the law already existing, and executed by the President's representatives, the officers of the United States army. This despotic form of administration is not an ideal method; its justification is that no other is practicable.

In using the army officers for administrative work, we should be doing nothing new. The first act relating to Louisiana, in 1803 , empowered the President to appoint all civil, military and judicial officers of the new territory, define their duties and support them with the army and navy. "It was in effect the establishment of a military despotism over Louisiana, and may suffice as an example of the extent to which the sovereign power of the United States over territories might go, if a wiser policy were not the rule," writes Alexander Johnston. The untaxed Indians, who are expressly excluded from the right of representation, have at times been cared for by our army officers acting as agents, and with a success in agreeable contrast to that of the average Indian agent.

There are two qualities among many, which the history of the British in India emphasizes as peculiarly desirable in those persons who have to govern dependent peoples. One is physical strength and courage; the other a high sense of honor. Those splendid men who saved India in the Mutiny, men both in the civil and military service, the two Lawrences, Edwards, Neville Chamberlain, Roberts, Johrı Nicholson and many like them, may well serve as examples of the value of these qualities. Their courage and vigor won the native admiration; their honorable dealing won confidence and love. The relationship between governor and governed is a fiduciary one, like that between guardian and 
ward. Its basis must be the sense of honor. Now is it not more likely that we shall find the union of these two qualities in our army officers of West Point training, than amongst any other class of citizens available for such work ? They are taught both to obey and to command. They are picked men, physically. Honor is the basis of the army organization, for conduct unbecoming an officer and a gentleman costs a man his commission. Just so far as the influence of politics and of politicians can be excluded, the regular army is to be trusted. We must use it to obtain order ; I believe that we can and must use it also to maintain order and administer justice.

There will be difficulties in the way. One will be the siatus of foreigners in the Philippines. We cannot grant them exterritorial privileges, for that would be inconsistent with our dignity; nor can we deny them civil rights, particularly when specified by treaty with their country; our own citizens would be likewise in a false position. Some makeshift would be required, like a plaster to a sore spot, for instance the application of the laws of Oregon and a Federal Court to others than natives. Another difficulty may arise from the religious orders. These friars serve as parish priests; they are large holders of property; this property is secured to them under the terms of the Spanish treaty, preventing sequestration; the educational system, such as it is, is in their hands. In Spanish times the church constantly intrigued against any governor who preferred the interests of the state to its own, and this same spirit, perhaps stirring up native opposition, we must expect to encounter.

Then there is the raising of revenue. Under Spanish rule, the larger items of income came from fifteen days' forced labor per head, per annum, or its commutation, five million dollars and over; from customs, two millions; from government monopolies, stamps, gambling, opium, cock-fighting, and so on, one million; from lotteries, one-half million. 
Much of this is not a proper source of revenue for an enlightened nation. Even with these illegitimate sources of income, Spain made a deficit. "There is no record," writes Foreman, "that the Philippines have ever been in a flourishing financial condition."

Lastly, there is always the chance that Congress, in order to embarrass a president of a different political complexion, may decide to embark upon civil government, and take this tremendous, perhaps dangerous, despotic power out of the Executive's hands.

So that we can hardly expect plain sailing. Our duty is to respect the Constitution, patiently and loyally to do our best under the circumstances, and then to "wish for the day." 